\title{
Energy Security as a Rationale \\ for Governmental Action
}

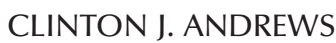
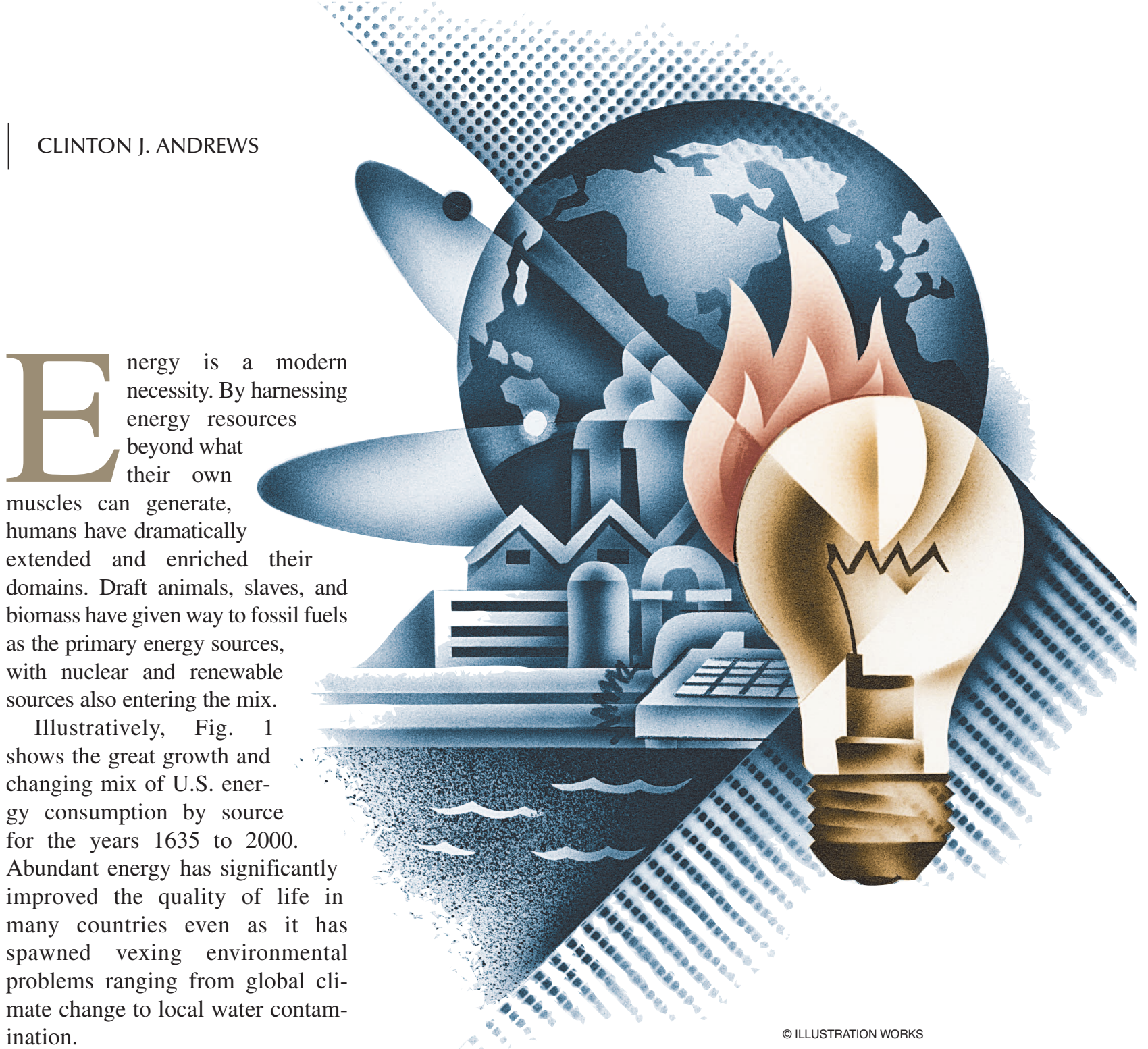

nergy is a modern necessity. By harnessing energy resources beyond what their own

muscles can generate, humans have dramatically extended and enriched their domains. Draft animals, slaves, and biomass have given way to fossil fuels as the primary energy sources, with nuclear and renewable sources also entering the mix.

Illustratively, Fig. 1 shows the great growth and changing mix of U.S. energy consumption by source for the years 1635 to 2000 . Abundant energy has significantly improved the quality of life in many countries even as it has spawned vexing environmental problems ranging from global climate change to local water contamination.

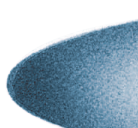


Political leaders have paid close attention to available energy supplies because of strong links between growth in energy consumption and the economy. The crucial role of fossil fuels in supporting mechanized warfare has further sharpened the politicians' focus. The uneven distribution of fossil fuel resources across the globe has forced national leaders to treat energy as a strategic commodity.

Energy security, therefore, has been a common rationale for governmental actions over the past century. I use Yergin's definition: "The objective of energy security is to assure adequate, reliable supplies of energy at reasonable prices and in ways that do not jeopardize major national values and objectives" [2, p. 111]. In this article, a brief examination of the histories of oil and electricity confirms that unfettered markets do not ensure adequate energy security, that rationales for governmental intervention have evolved over time, and that economic and political interests have been inextricably interlinked throughout.

The energy security lens also has significant implications in the current policy debate over the "hydrogen economy."

\section{Brief History of Oil}

Like many resource markets, the market for petroleum suffers from dramatic and persistent price volatility. Demand is unresponsive to price in the short run, yet growth in supply is lumpy and capitalintensive, and hence it is difficult to balance demand and supply. Natural equilibrium is unlikely, so both consumers and producers seek external interventions that improve price stability. When the oil era took off in the late $19^{\text {th }}$ century, "John D. Rockefeller's original solution to the problem of price volatility was to establish a monopoly" [3, p. 2].

Gillespie and Henry [3, p. 3] identify five successive oil regimes: 1) the Standard Oil monopoly, broken up in 1911; 2) the Texas Rail- road Commission's internationally influential pro-rationing of production, starting in the 1930s; 3) the partly contemporaneous Seven Sisters cartel consisting of Exxon, Shell, British Petroleum, Mobil,

[2, p. 122]. For example, two thirds of U.S. oil consumption is currently for transportation, and demand is extremely inelastic because few ready substitute fuels exist [5]. In oil producing countries, petroleum sales

\section{Unfettered markets do not ensure adequate energy security.}

Chevron, Texaco, and Gulf, which lasted into the 1970s; 4) the Organization of Petroleum Exporting Counties (OPEC) that started in 1960 but became effective only briefly during the 1970s-1980s; and 5) the Saudi-American regime under whose twilight years we currently are living.

Politicians helped create and preserve these oil regimes at every turn [3], [4]. Rockefeller depended on compliant, laissez-faire legislators for Standard Oil's monopoly. The Texas Railroad Commission, by 1935 an elected body beholden to small independent oil producers, was able to use pro-rationing quotas to establish price floors that also benefited the international majors for over 40 years. The Seven Sisters, although they relied on an interlocking set of private contracts to enforce stable market shares and prices, also depended on British and American governmental interventions to prevent producing countries from nationalizing their oil. OPEC, conversely, depended on governmental enforcement of national production quotas. The Saudi-American regime depends on the Saudi willingness to be a swing producer and an American willingness to intervene militarily in a politically unstable part of the world.

Political interest in this economic commodity is not merely cynical it is also prudent. In oil consuming countries, "shocks -interruptions, disruptions and manipulations of supply - can lead to sudden, sharp increases in prices and can impose heavy economic and political costs" may represent the vast majority of foreign exchange earnings, so a drop in prices or quantities creates economic and political chaos.

Table I summarizes recent oil export and import dependence statistics for selected countries. Over the past century, the United States has gone from being the world's predominant oil supplier to being its largest importer. Much of the U.S. angst over energy security in recent decades comes from its change in status into a significant net importer, as shown in Fig. 2. Net imports grew from 0 to 11.2 million barrels per day between 1949 and 2003, with the nation importing more than it produced from 1994 onward [5], [6]. U.S. net oil imports cost $\$ 122$ billion in 2003 and represented $23 \%$ of the nation's trade deficit [7]. Japan and most European countries have always imported almost all of the oil they consumed, and they have long since adapted their economies and policies. China became a net importer in 1993, and imports grew to about 2 million barrels per day by 2002 [8].

\section{Oil Security}

A number of changes to the global oil marketplace since the severe shocks of 1973 have made oil markets much more secure and have allowed economic rather than political factors to govern most of the time. First, in 1975, importing countries created the International Energy Agency (IEA), which developed a deterrent oil supply allocation system for supply disruptions. Second and more important, importing countries diversified away 


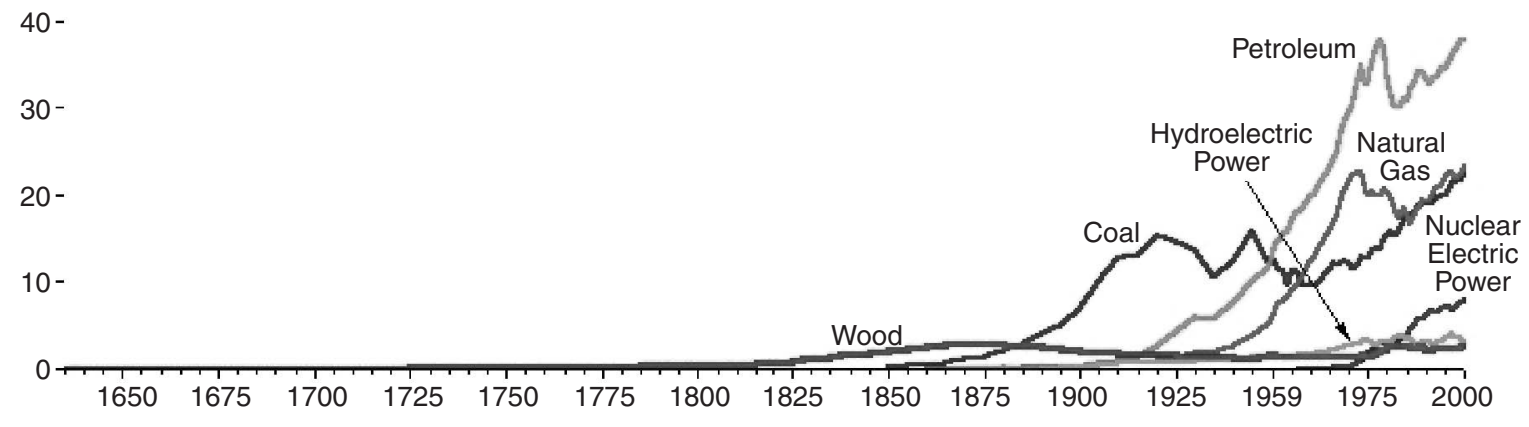

Fig. 1. U.S. energy consumption by source, 1635 - 2000 (Quadrillion BTU). Source: [1]

from Middle Eastern oil towards oil elsewhere, and towards coal, natural gas, and other fuels, while also greatly increasing their energy efficiency. Third, importing countries developed strategic petroleum reserves to carry them through short-term supply disruptions. Fourth and arguably most important, the IEA developed a worldwide information system that vastly increased the transparency of the oil market and allowed it to adapt quickly and accurately to changing conditions [11].

Conditions have also changed dramatically on the supply side since 1973. Although Middle Eastern countries continue to hold the vast majority of reserves, they currently represent only $28 \%$ of global production, down from 37\% in 1973 [14]. Non-Middle eastern and non-OPEC producers have ramped up production and greatly diversified the geog-

Table I

Petroleum Balance of Trade for Selected Countries in 2001

\begin{tabular}{lc|lcc}
\hline Importers & Exporters & & \\
\hline Country & $\begin{array}{c}\text { Oil Imports } \\
\text { as \% of } \\
\text { Consumption }\end{array}$ & Country & $\begin{array}{c}\text { Oil Exports } \\
\text { as \% of } \\
\text { Consumption }\end{array}$ & $\begin{array}{c}\text { Oil as \% } \\
\text { of Export } \\
\text { Earnings }\end{array}$ \\
\hline China & 31 & Canada & 41 & 14 \\
France & 96 & Iran & 176 & 85 \\
Germany & 95 & Nigeria & 640 & 98 \\
Haiti & 100 & Norway & 3042 & 57 \\
Iceland & 100 & Saudi Arabia & 477 & 90 \\
Japan & 98 & UK & 45 & 8 \\
Jordan & 100 & Venezuela & 399 & 73 \\
USA & 55 & Vietnam & 111 & 20 \\
& & & & Sources: [9-12]
\end{tabular}

would be sold. Producers are at best interdependent with consumers in the longer run because, as an Iranian-born colleague observes, "we cannot drink our oil" [17].

Energy security has rarely been the sole driver of political and military action. Before World War I, Standard Oil, in pursuit of profits and market power, persuaded a beholden U.S. government to intervene in the internal affairs of several Middle Eastern oil states. The U.K. redrew the map of the Middle East in the waning days of Empire in part for administrative convenience. France and the United States intervened in oil-rich Viet Nam in the 1950s and 1960s mostly to slow the spread of communism. In the 1960s, oilfields in many countries were nationalized to return control over these resources to local decision makers. Western responses to the Arab oil embargo of 1973 were also a gesture of solidarity with Israel. The blockade of Iran in 1979 in part reflected western disapproval of hostage taking. The first Gulf war in 1991 was a direct response to the invasion of one sovereign nation by another. The second Gulf war in 2003 was also about deposing a dictator who had threatened to use weapons of mass destruction. The voluminous historical literature on oil confirms, first, that the energy security rationale is widely used, and second, that other factors may be equally important in driving governmental actions. 


\section{Electricity}

The electricity sector also explicitly sought governmental involvement during its development, and by the 1930s it was widely accorded public utility status [18]. Electricity supply is capital-intensive, storage is minimal, transmission and distribution are intrusive, and until recently price signals have been weak. As a remedy to under-financing in most of the world, electricity has been supplied by public enterprises or regulated private enterprises that have been granted monopoly franchises [19]. Recent deregulatory efforts have reduced but not eliminated a governmental role [20].

Security concerns for electricity have focused mostly on adequacy of supply (is there enough capacity?) and reliability of operations (are all of the components functioning properly?). In wartime, and recently with the increase in terrorist threats, security of the physical and informational infrastructures also has received attention.

The primary sources of electrical energy are quite diverse, currently including coal, oil, gas, biomass, hydropower, nuclear, wind, geothermal, and solar. Each source has strengths and weaknesses. Renewables are the great hope of many, and they represent the most rapidly growing element of the electrical energy mix. Unit costs have dropped by an order of magnitude for wind and solar since the 1970s, and wind is now economically viable [21], [22]. Enthusiasts argue that the diffuse renewable resources and decentralized locations of solar panels and wind turbines makes such power sources inherently more secure than large, central station power plants the targets are dispersed. It remains an open issue whether distributed generation can be financed and operated as cost-effectively as central station power plants.

Nuclear power adds one more dimension to the security picture. It beneficially provides an alternative to fossil fuels, but imposes nuclear weapons proliferation risks as well as offering attractive physical targets for saboteurs. There is a strong case favoring continued investment in nuclear power innovations, but only if the associated proliferation and security risks can be resolved [23].

Concern over the physical security of energy facilities needs to be kept in perspective [24]-[26]. A strategy of eliminating all large targets would mean eliminating aspects of civilization we value highly, such as our great cities and ment of Energy's history website (other countries' policies cover a similar range) [27]:

August 30, 1954. President Eisenhower signs the Atomic Energy Act of 1954, opening the way for development of a civilian nuclear power program.

July 6, 1962. President Kennedy condones a test in Sedan, Nevada as part of the Plowshare program seeking to develop peaceful uses for nuclear explosives.

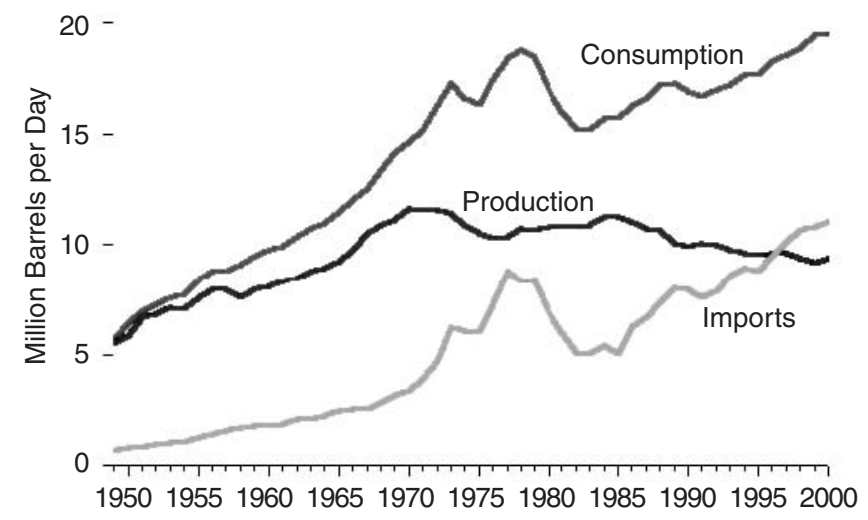

Fig. 2. U.S. petroleum overview: 1949 - 2000. Source: [5]

monuments. Following September 11, 2001, advocates of sprawling suburban land use patterns argued that central cities should wither away because they were not defendable. Abandoning all central station power plants for the same reason sounds equally nonsensical.

\section{U.S. Energy Policy Rationales}

A scan of recent headlines can confirm that there are multiple rationales for governmental intervention in the energy economy. Concerns over air pollution, global warming, energy prices, adequacy and reliability of supplies, foreign trade deficits of energy importing nations, and military adventurism get continual play, decade after decade. To illustrate, following are the objectives of a half-century of U.S. federal energy policies as paraphrased from the U.S. Depart-
January 1, 1969. President Johnson signs the National Environmental Policy Act.

November 7, 1973. President Nixon launches Project Independence, with the goal of achieving energy self-sufficiency by 1980.

December 22, 1975. President Ford signs the Energy Policy and Conservation Act, extending oil price controls into 1979, mandating automobile fuel economy standards, and authorizing creation of a strategic petroleum reserve.

April 20, 1977. President Carter unveils the first National Energy Plan for managing America's energy future.

April 5, 1979. President Carter, responding to growing energy 
shortages, announces gradual decontrol of oil prices and proposes a windfall profits tax. Carter subsequently announces a program to increase the nation's use of solar energy, including a solar development bank and increased funds for solar energy research and development. Soon thereafter, President Carter proclaims a national energy supply shortage and establishes temperature restrictions in nonresidential buildings, and then declares energy to be the immediate test of government's ability to unite the
March 26, 1986. DOE releases fifth National Energy Policy Plan stressing a continued goal of adequate supply of energy available at reasonable cost.

March 17, 1987. President Reagan's Energy Security Report outlines Nation's increasing dependence on foreign oil.

December 21, 1990. President George H.W. Bush unveils his National Energy Strategy, which leads to the Energy Policy Act of 1992 that includes federal appli-

\section{Rationales for governmental intervention have evolved over time.}

Nation and proposes an $\$ 88$ billion decade-long effort to enhance production of synthetic fuels from coal and shale oil reserves.

January 31, 1980. Following the May release of Carter's second National Energy Plan, Energy Secretary Duncan tells Congress that DOE's mission is to assure the Nation's orderly transition from an economy dependent on oil to an economy relying upon diversified energy sources.

July 17, 1981. President Reagan's DOE releases third National Energy Policy Plan. Plan's free market emphasis is intended to reduce government regulations and subsidies.

October 4, 1983. President Reagan's fourth National Energy Policy Plan emphasizes conservation, decontrol of natural gas, research, and nuclear licensing reform.

April 23, 1985. In his first major policy speech of Reagan's second term, Secretary Herrington calls for "energy strength" built upon existing "stability and security." ance efficiency standards, plus electric and gas utility deregulation.

April 1994. President Clinton releases DOE's first comprehensive strategic plan, entitled "Fueling a Competitive Economy," which identifies five core mission areas: industrial competitiveness, energy resources, national security, environmental quality, and science and technology." Lacking legislative success, Clinton uses administrative actions to continue electricity deregulation and support conservation and renewables.

January 2001. President George W. Bush asks a task force to "develop a national energy policy designed to help the private sector, and, as necessary and appropriate, State and local governments, promote dependable, affordable, and environmentally sound production and distribution of energy for the future." This controversial "Cheney" plan, which emphasizes supply-side strategies, is released on May 17, 2001.

October 1, 2002. Bush Energy Secretary Spencer Abraham revises
DOE's mission following September 11, 2001: "we share a common overarching mission: national security."

January 28, 2003. In his State of the Union address, President Bush says: "With a new national commitment, our scientists and engineers will overcome obstacles to taking these (hydrogen fuel cell) cars from laboratory to showroom, so that the first car driven by a child born today could be powered by hydrogen, and pollution-free."

Over the decades, we see the rationales for governmental action shift. Eisenhower and Kennedy both put government in the position of technological leader of the civilian energy economy. Johnson seeks to curb energy sector pollution. Nixon responds to the Arab oil embargo with price and quantity controls and an ambitious drive for energy independence. Ford stays this course. Carter returns much control to the free market but places governmental bets on conservation, renewables and synthetic fossil fuels. Reagan further reduces the governmental roles in the energy marketplace and in research. Bush I imposes efficiency standards while continuing deregulation and launching the Gulf War. Clinton likewise continues to deregulate while favoring demandside efficiency measures. Bush II tilts heavily toward policies favoring supply-side growth in fossil fuels, and boosts fuel cell cars, while invading Afghanistan and Iraq. Playing out here are two intertwined debates. First, how should responsibility for energy security be allocated between the economic and political spheres? Second, which types of governmental intervention are most appropriate?

Some authors insist that the discourse is unfolding in only one direction: governments that learned to intervene aggressively during World War II are now stepping back 
into more modest roles, and they are learning to trust the marketplace again [13], [28]. Others see pendulums swinging back and forth between consumer and producer interests [29], [30], or between a centralized "hard" energy path and a decentralized "soft" path [31], [32].

\section{Classical Rationales for Governmental Action}

Given the $20^{\text {th }}$ century experience with communism and fascism, a reasonable starting point for $21^{\text {st }}$ century public policy might be Hippocrates: "above all, do no harm" $\left[33\right.$, p.43]. Inspired by the $18^{\text {th }}$ century laissez faire advocate Adam Smith, who wanted government to be no more than a night watchman for the economy, classical liberals have argued that government should serve only as rule maker and umpire for the economic game [34].

Practical minimalists say that government should only intervene in the marketplace for three reasons: to improve allocational efficiency, distributional equity, and macro stability [35]. The efficiency rationale is all about correcting market failures. In the energy sector, the most important of these are monopoly power (as enjoyed by electric utilities, for example), externalities (especially the environmental damage caused by extracting and burning fossil fuels), and public goods (providing things like national security and basic research which the unfettered marketplace under-provides). The equity rationale justifies "lifeline" electricity and gas rates and assistance to help low-income families pay heating bills. The macro stability rationale justifies interventions to manage foreign trade decifits, inflation, and the economy-wide balance between consumption and investment.

Others see a larger role for government, and the evidence certainly shows that governments frequently act in order to enforce national norms, pursue national objectives, and cater to special interests [28],
[36]-[39]. For energy, the essential tension is not merely whether it is an economic issue to be managed in the marketplace or a political issue to be managed by government - it is often, more subtly, whether a particular problem is an economic issue to be managed by government.

Actual governmental interventions in the energy economy come in many flavors, and they typically address multiple objectives. Indeed, the historical record shows that security on its own has dictated only a few actions: establishing strategic petroleum reserves, increasing the diversity of sources of energy supplies, and physically protecting energy infrastructures and supplies. Most energy policies are determined at least as strongly by the other objectives implicit within Yergin's definition: "to assure adequate, reliable supplies of energy at reasonable prices and in ways that do not jeopardize major national values and objectives" [2, p. 111]. This begs a question: do public policies make unreasonable tradeoffs between security and other objectives?

\section{The Special Role of Energy Carriers}

Electricity is an energy carrier, meaning that it transforms diverse primary energy sources such as coal and nuclear energy into a clean, convenient, easy-to-deliver form for final use. This carrier has proved to be of immense value to the macro-economy for allowing the diversification of energy supplies. In response to the oil price spikes of the 1970s, the U.S. electricity sector, for example, diversified away from oil towards coal and eventually natural gas to such an extent that it is visible in the multi-century graph in Fig. 1. It is fair to say that electricity reversed decline in the U.S. coal industry by preventing oil and gas from competitively displacing the dirty, high-carbon fuel, and the nation now burns far more coal than it did at the height of the industrial revolution. This substantial shift away from oil was accelerated by a shift towards an increased share for electricity of end use consumption.

Hydrogen is being proposed as an energy carrier for mobile and cogeneration applications, just as electricity has served so successfully an energy carrier for stationary applications. Hydrogen is a cleanburning gas that can be produced from a variety of primary sources and delivered to the point of use. In particular, proponents of fuel cell technology hope that hydrogen emerges as a viable energy carrier because other potential feedstocks such as methanol require processing before use [40]. Given that transportation today depends almost exclusively on petroleumbased fuels, and viable substitutes do not seem to be at hand, advocates hope that hydrogen offers a solution to oil import dependence.

There is a high thermodynamic cost in the near-term of using hydrogen as an energy carrier. Most current U.S. hydrogen is produced by reforming natural gas, although some is also created by electrolyzing water [41]. Both reforming and electrolysis are relatively inefficient processes with unappetizing theoretical engineering efficiency limits [40]. One can argue that low engineering efficiency only matters when consuming non-renewable fossil fuels, and it should not be a concern when using abundant renewable energy. However, if that renewable energy can be more efficiently converted to an alternative energy carrier-electricity-then turning it into hydrogen may not be cost-competitive [42].

Electricity systems themselves are not very energy-efficient. Fossil fuel-fired power plants convert only about $30-50 \%$ of the heating value of the fuel into electricity; then resistance losses within transmission and distribution systems impose an additional tax of about $10 \%$ [18]. Yet ubiquitous electricity 
systems demonstrate that we are willing to sacrifice much thermodynamic efficiency in exchange for cleanliness and convenience at the point of use. The same may someday be true for a hydrogen energy carrier: this is the compelling logic of economic efficiency, not engineering efficiency.

Some types of environmental impacts - greenhouse gas emissions, for example - tend to track engineering efficiency very closely, so that lower losses at any stage in the system lead to lower emissions, all else being equal [41]. Other types of environmental impacts sulphur dioxide emissions, for example - can be mitigated by fuel substitution or flue gas scrubbing, and hence they do not closely track engineering efficiency [43]. The most reliable and cost-effective current multi-pollutant mitigation strategies tend to include efficiency improvements as a key element [44]. However, single-pollutant strategies such as carbon sequestration may have a future role [41]. Carbon sequestration systems now under development could capture carbon at a fossil fueled power plant and deliver it to underground cavities or the deep ocean for permanent storage, while adding roughly $50 \%$ to the cost of the electricity so generated [45].

Energy carriers may also impose security-environment tradeoffs precisely because they facilitate fuel diversification. Just as electricity has increased dirty coal usage, so a hydrogen carrier could increase the use of various fossil fuels.

\section{The Hydrogen Case}

Current policy debate over the "hydrogen economy" illustrates the interplay of rationales for governmental intervention in the energy marketplace. Elements of the hydrogen vision include hydrogen-consuming fuel cells for mobile, stationary, and appliance uses; hydrogen production technologies; and a vast hydrogen delivery infrastructure. All elements exist today but they do not perform satisfactorily and are not yet in widespread use. Competing visions vie for attention: some advocate a centralized solution involving hydrogen produced by nuclear or coal-fired power plants and delivered by continental networks of hydrogen pipelines. Others advocate a decentralized solution in which hydrogen is produced by local renewables or by natural gas that is reformed at the point of end use.

At a recent conference, a former U.S. Congressional leader [46] listed the anticipated benefits of moving toward a hydrogen economy:

n improved access to unlimited amounts of energy;

- geopolitical advantages to consumer nations due to increased energy independence;

- distributed power, which aligns with a megatrend toward decentralization, customization, and security (dispersed targets);

- reduced environmental impacts of transportation because hydrogen fuel cells emit only water vapor; and

- spurred creation of higher quality products such as cars that can double as power plants or laptop computers with very long-lasting power supplies.

The barriers to achieving a hydrogen economy include:

- Mostly negative public perceptions of hydrogen (Hindenberg explosion, H-bomb, hydrogen bubble at the Three Mile Island nuclear accident);

- Need for substantial investments in hydrogen research and production technology;

- Need for the creation of a ubiquitous hydrogen delivery infrastructure; and the

- High cost of fuel cells and hydrogen production technologies.
Skeptics [47]-[49] advocate instead for higher efficiency vehicles and appliances, and increased basic research funding for new primary energy sources such as photobiologically produced hydrogen. Some even say that electricity is the only universal energy carrier needed in the near term [42]. The skeptics have engineering efficiency arguments on their side, as Table II suggests. Whether they also have economic arguments on their side depends in part on how we count benefits and costs.

Many of the necessary technologies for a hydrogen transition are immature and costly in comparison with conventional fuels and prime movers. Thus the current hydrogen value proposition is extremely unattractive for most energy users. A variety of technology roadmap studies [40], [41], [50]-[52] suggest that $50 \%$ and greater cost reductions are needed before hydrogen and fuel cells can compete successfully in the automotive market.

The calculus changes dramatically if security-related benefits are included. Suppose that energy security represented $50 \%$ of the rationale for the American war on Iraq in 2003-2004 (the spectrum of views on this matter ranges from 0 to $100 \%$ ). A well-regarded study of the likely costs of invading and occupying Iraq places the costs to the United States in a range from $\$ 99$ billion to $\$ 1,924$ billion over the decade following the war [53]. Included are direct military costs, occupation and peacekeeping, reconstruction and nation-building, humanitarian assistance, impacts on oil markets, and macroeconomic impacts. Direct U.S. governmental expenditures as of this writing exceed $\$ 120$ billion [54], suggesting that $\$ 200$ billion is a plausible central estimate of the Iraq invasion's overall cost to the U.S. economy. Fifty percent of that amount is $\$ 100$ billion. In comparison, the United States has spent an average of $\$ 21$ billion annually on Persian 
Table II

Full System Efficiencies of Alternative Types of Cars

\begin{tabular}{|c|c|c|c|c|c|c|c|c|c|c|c|c|c|c|c|c|c|c|c|}
\hline $\begin{array}{r}\text { Efficiency of each } \\
\text { production stage } \\
(1-\text { eff. factors shown } \\
\text { in table cells): }\end{array}$ & 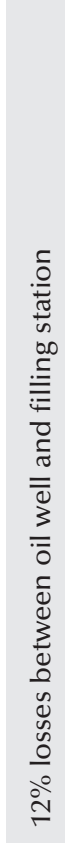 & 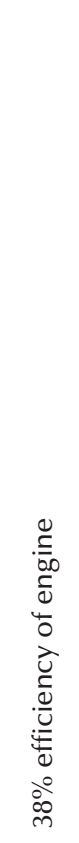 & 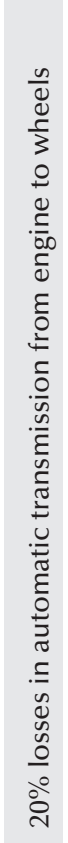 & 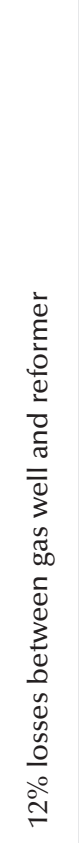 & 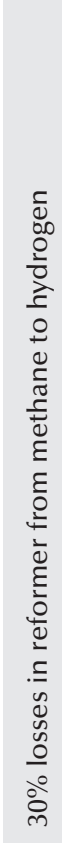 & 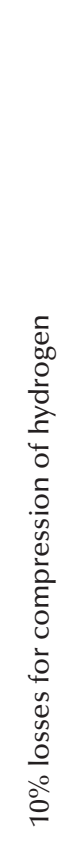 & 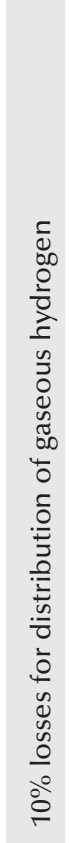 & 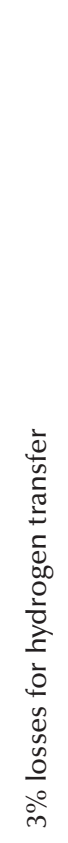 & 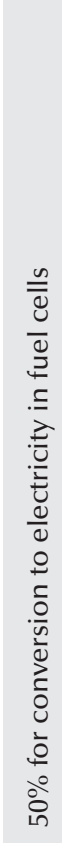 & 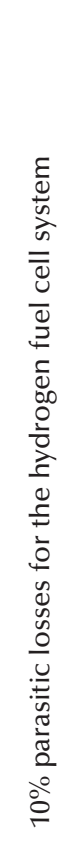 & 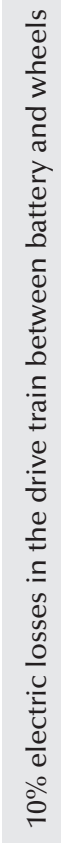 & 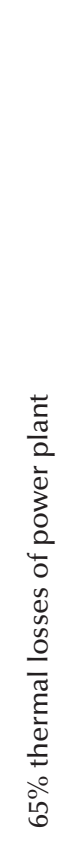 & 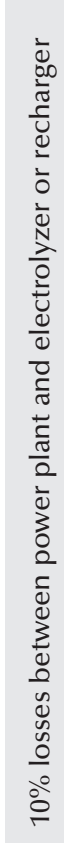 & 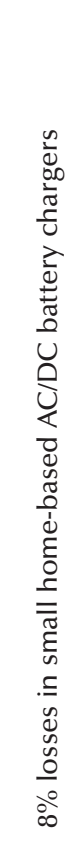 & 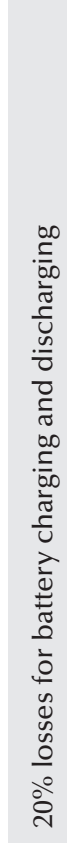 & 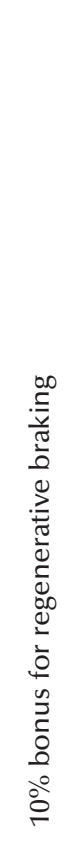 & 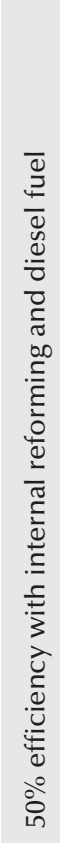 & 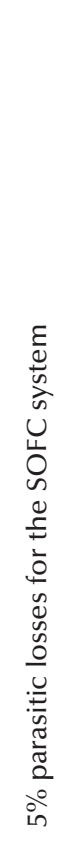 & 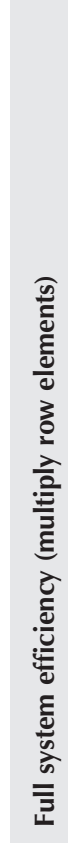 \\
\hline $\begin{array}{l}\text { Current technology } \\
\text { car with gasoline } \\
\text { fueled internal } \\
\text { combustion }(30.6 \\
\text { miles/gallon) }[58,59]\end{array}$ & 0.88 & 0.38 & 0.80 & & & & & & & & & & & & & & & & $27 \%$ \\
\hline $\begin{array}{l}\text { Fuel cell car operated } \\
\text { on gaseous hydrogen } \\
\text { from methane steam } \\
\text { reformer [adapted } \\
\text { from [60]] }\end{array}$ & & & & 0.88 & 0.70 & 0.90 & 0.90 & 0.97 & 0.50 & 0.90 & 0.90 & & & & & & & & $20 \%$ \\
\hline $\begin{array}{l}\text { Fuel cell car operated } \\
\text { on gaseous hydrogen } \\
\text { from electrolysis via } \\
\text { coal-fired power plant } \\
\text { [adapted from [60]] }\end{array}$ & & & & & 0.70 & 0.90 & 0.90 & 0.97 & 0.50 & 0.90 & 0.90 & 0.35 & 0.90 & & & & & & $7 \%$ \\
\hline $\begin{array}{l}\text { Fuel cell car operated } \\
\text { on gaseous hydrogen } \\
\text { from electrolysis via } \\
\text { wind farm [adapted } \\
\text { from [60]] }\end{array}$ & & & & & 0.70 & 0.90 & 0.90 & 0.97 & 0.50 & 0.90 & 0.90 & & 0.90 & & & & & & $20 \%$ \\
\hline $\begin{array}{c}\text { Electric car recharged } \\
\text { by coal-fired power } \\
\text { plant [adapted from } \\
[60]]\end{array}$ & & & & & & & & & & 0.90 & 0.35 & 0.90 & 0.92 & 0.80 & 1.10 & & & & $23 \%$ \\
\hline $\begin{array}{l}\text { Electric car recharged } \\
\text { by wind farm }[60]\end{array}$ & & & & & & & & & & 0.90 & & 0.90 & 0.92 & 0.80 & 1.10 & & & & $66 \%$ \\
\hline $\begin{array}{l}\text { Hybrid electric car } \\
\text { with Diesel-fuelled } \\
\text { solid oxide fuel cell as } \\
\text { range extender [60] }\end{array}$ & 0.88 & & & & & & & & & 0.90 & & & & & 0.80 & 1.10 & 0.50 & 0.95 & $33 \%$ \\
\hline
\end{tabular}


Gulf oil imports in recent years [55], putting the cost of the war at one half of the decadal cost of the oil. If such a war happens roughly once per decade, as it has recently, a conservative markup of $50 \%$ on Persian Gulf oil would be necessary to internalize just the energy security portion of the U.S. cost of the Iraq war. Not included are costs to other countries and loss of life. On this basis, one can justify billions of dollars annually in expenditures on "expensive" hydrogen technology that avoids wartime costs. Of course, one could equally well invest those billions in energy efficiency, renewable energy, or non-Persian Gulf fossil fuel resources.

Environmental costs and benefits of a switch to hydrogen are indeterminate, depending on whether it is "dirty" or "clean" hydrogen. Dirty hydrogen is produced from fossil fuels at a low full system efficiency, and contributes to global warming as well as local environmental problems associated with the extraction and delivery of fossil fuels. Clean hydrogen is produced from renewable sources at higher full system efficiencies, and with fewer harmful environmental impacts. The only sure environmental benefits come from avoided air pollution at the point of use, the avoided direct health costs of which alone are on the order of $\$ 100$ million annually for a place like New Jersey, USA, with a mostly suburban population of about 8 million [56].

Rifkin harbors rather more subversive hopes for hydrogen [57]. He argues that great human transitions happen when a new energy source (distributed renewable generation) becomes available in conjunction with a new communication mechanism (the internet), leading to a densification of human exchange. By analogy, we would need to reconfigure the electric grid to allow peer-to-peer energy flows. But since renew- ables are intermittent energy sources (no solar power at night, no wind power when it's calm), we need an energy storage carrier: hydrogen. Bottom up and top down forces will interact uneasily to make distributed generation work. The current U.S. vision of the hydrogen economy is centralized and fossil fuel based, whereas the European vision is decentralized and renewable. To promote democracy we need to decentralize control over energy and collectively organize energy consumers. Then, hopes Rifkin, the hydrogen economy can promote a better world by means of "reglobalization from the bottom up."

The potential importance of hydrogen as an energy carrier can be overstated, but it nevertheless appears significant. Energy security by means of oil import substitution is the primary goal of current OECD country hydrogen policies, with environmental benefits secondary.

\section{Energy Security as a Policy Driver}

Energy security persists as a policy driver of great rhetorical and practical importance. Although the world is not yet short of petroleum, its concentration in a few politically unstable areas already has profound effects. The United States has recently demonstrated its willingness to spend a full year's worth of world oil industry revenues on regime change in Iraq. Governments could instead spend similar amounts-perhaps just as wastefully but with less loss of human life-on the development of energy efficiency technologies, alternative domestic energy sources and perhaps even new energy carriers like hydrogen.

For a century now, importing nations have done whatever it takes to ensure a continuing flow of energy to fuel their economies. The continuing troubled geopolitics of oil confirms the salience of the security rationale. Ensuring access to oil and gas has been an element of - but never the sole justification for - many military and diplomatic interventions in the Middle East, and to a lesser extent in Southeast Asia and Latin America [4], [16].

The security rationale tells governments to act, but doesn't specify how. There are lots of possible responses. Balanced public policy should optimize across security, economic, and environmental criteria, and not maximize any one criterion. This is the crux of current policy debates - is there a way to achieve energy security without jeopardizing other major national values and objectives? One solution, self-sufficiency, is an economically costly strategy that also deprives energy exporting nations of needed trade opportunities. Another solution, increasing the diversity of energy supplies, is beneficial for security and economic stability, but not necessarily for the environment. A related solution, supporting hydrogen as an energy carrier, has related weaknesses.

Policymakers will never find the "sweet spot" that balances security, economic, and environmental interests until there is more agreement that these are all equally valid national values and objectives. Thus, the hydrogen economy solution will face vocal opposition until public policy settles on the "clean" (rather than "dirty") hydrogen pathway. Ideological debate over the decentralization of energy production likewise merely polarizes. We would be better served by wider experimentation that identifies practical and balanced solutions.

\section{Author Information}

Clinton Andrews is Associate Professor and Director of the Program in Urban Planning and Policy Development, E.J. Bloustein School of Planning and Public Policy, Rutgers University, 33 Livingston Ave, New Brunswick, NJ 08901; email: c.j.andrews@ieee.org. 


\section{References}

[1] U.S. Department of Energy, Energy Information Administration, Energy in the United States: 1635 - 2000. Downloaded May 22, 2004 from http://www.eia.doe.gov/emeu/aer/eh/frame.html. [2] D. Yergin, "Energy security in the 1990s," Foreign Affairs, vol. 67, no. 1, Fall 1988.

[3] K. Gillespie and C.M. Henry, "Introduction," in Oil in the New World Order, K. Gillespie and C.M. Henry, Eds. Gainesville, FL: University Press of Florida, 1995, pp. 1-17.

[4] D.A. Yergin, The Prize: The Epic Quest for Oil, Money and Power. New York, NY: Simon and Schuster, 1991.

[5] Energy Information Administration, Energy in the United States: 1635 - 2000. Washington, DC: U.S. Department of Energy, Oct. 2002, http://www.eia.doe.gov/emeu/aer/eh/frame.html. [6] Energy Information Administration, Country Analysis Brief: United States. Washington, DC: U.S. Department of Energy, Apr. 2004, http://www.eia.doe.gov/emeu/cabs/usa.html.

[7] Energy Information Administration, "Table 1.5: Merchandise Trade Value," Monthly Energy Rev., Washington, DC: U.S. Department of Energy, June 2004, http://www.eia.doe.gov/ emeu/international/petroleu.html\#IntlTrade.

[8] Energy Information Administration, Country Analysis Brief: China. Washington, DC: U.S. Department of Energy, June 2003, http://www. eia.doe.gov/emeu/cabs/china.html.

[9] Energy Information Administration, International Energy Annual 2001. Washington, DC: U.S. Department of Energy, Apr. 2004.

[10] U.S. Department of State, Background Notes for Venezuela, Norway, Iran, Saudi Arabia, Nigeria, Vietnam, 2004; http://www.state. gov/r/pa/ei/bgn/

[11] Natural Resources Canada, Energy Indicators for Sustainable Development, Indicator 1.3 Value of Energy Exports, 2004 http://www2. nrcan.gc.ca/es/es/sdi/English/

[12] National Statistics, Canada, General Summary of Trade: Trade in Goods, 2004 www.statistics. gov.uk/StatBase

[13] D. O'Brien, "Mightier than the sword," Harvard Int. Rev., vol. 19, no. 3, Sum. 1997.

[14] Energy Information Administration, Monthly Energy Review. Washington, DC: U.S. Department of Energy, Apr. 2004

[15] K.S. Deffeyes, Hubbert's Peak: The Impending World Oil Shortage. Princeton, NJ: Princeton Univ. Press, 2001.

[16] H. Amirahmadi, "World oil and geopolitics to the Year 2010," J. Energy and Development, vol. 21 , no. $1,1996$.

[17] H. Amirahmadi, personal communication, May 4, 2004.

[18] L.S. Hyman, America's Electric Utilities: Past, Present and Future, 4th ed. Arlington, VA: Public Utilities Reports, 1992.

[19] R.F. Hirsh, Technology and Transformation in the American Electric Utility Industry. Cambridge, U.K.: Cambridge Univ. Press, 1989.

[20] T.J. Brennan, K.L. Palmer, R.J. Kopp, A.J. Krupnick, V. Stagliano, and D. Burtraw, A Shock to the System: Restructuring America's Electricity Industry. Washington, DC: Resources for the Future, 1996.

[21] Energy Information Administration, Renewable Resources in the U.S. Electricity Supply. Washington, DC: U.S. Dept. of Energy, Feb. 1993, http://tonto.eia.doe.gov/FTPROOT/ renewables/056192.pdf.
[22] Energy Information Administration, Renewable Energy Annual 2002. Washington, DC: U.S. Dept. of Energy, Nov. 2003, http:// www.eia.doe.gov/cneaf/solar.renewables/page/ rea_data/rea_sum.html.

[23] R.L. Garwin and G. Charpak, Megawatts and Megatons: A Turning Point in the Nuclear Age. New York, NY: Alfred A. Knopf, 2001.

[24] M.H. Cooper, "Energy Security: How Vulnerable is America's Energy System?, $C Q$ Researcher, vol. 12, no. 4, February 2002.

[25] J. Bielecki, "Energy security: Is the wolf at the door?," Quart. Rev. of Economics and Finance, vol. 42, pp. 235-250, 2002.

[26] H. Harvey, "America and the global energy challenge," Aspen Institute, June 2002.

[27] U.S. Department of Energy, Departmental History Website, downloaded on May 2, 2004 from http://ma.mbe.doe.gov/me70/history/ 19711980.htm.

[28] D.A. Yergin and J. Stanislaw, The Commanding Heights. New York, NY: Simon and Schuster, 1998

[29] M.A. Walls, "U.S. energy and environmental policies: Problems of Federalism and conflicting goals," in Making National Energy Policy, H.H. Landsberg, Ed. Washington, DC: Resources for the Future, 1993, pp. 95-130. [30] P. Lemaitre, "Energy Policy: EU Must Take Charge of its Own Fate," European Politics, Spring 2002.

[31] A.B. Lovins, Soft Energy Paths: Toward a Durable Peace. Cambridge, MA: Ballinger, 1977.

[32] A.B. Lovins and L.H. Lovins, Brittle Power: Energy Strategy for National Security. Andover, MA: Brick House Pubs, 1982.

[33] D.R. Bohi, "Searching for consensus on energy security policy," in Making National Energy Policy, H.H. Landsberg, Ed. Washington, DC: Resources for the Future, 1993, pp. 41-59. [34] M. Friedman, Capitalism and Freedom Chicago, IL: Univ. of Chicago Press, 1962/1982. [35] R.A. Musgrave, The Theory of Public Finance. New York, NY: McGraw Hill, 1959.

[36] J.M. Keynes, General Theory of Employment, Interest, and Money. New York, NY: Harcourt Brace, 1936.

[37] B.F. Skinner, Walden Two. New York, NY: Macmillan, 1962

[38] J.K. Galbraith, Economics and the Public Purpose. New York, NY: Signet, 1973.

[39] C.E. Cochran, L.C. Mayer, T.R. Carr, and N.J. Cayer, American Public Policy: An Introduction, 3rd ed. New York, NY: St. Martin's Press, 1990.

[40] J.M. Ogden, "Prospects for building a hydrogen energy infrastructure," Ann. Rev. of Energy and Environment, vol. 24, pp. 227-79, 1999.

[41] National Research Council, Committee on Alternatives and Strategies for Future Hydrogen Production and Use, The Hydrogen Economy: Opportunities, Costs, Barriers, and $R \& D$ Needs. Washington, DC: National Academies Press, 2004.

[42] U. Bossel, "The hydrogen illusion: Why electrons are a better energy carrier," working paper available from European Fuel Cell Forum, Morgenstrasse 2F, CH-5452 Oberrohrdorf, Switzerland, 2004a.

[43] S.R. Connors and C.J. Andrews, "Systemwide evaluation of efficiency improvements: Reducing local, regional, and global environmental impacts," in Energy and the Environment in the 21st Century, J. Tester, D. Wood, and N.
Ferrari, Eds. Cambridge, MA: M.I.T. Press, 1991, pp. 775-788.

[44] C.J. Andrews and S.R. Connors, "Existing capacity - The key to reducing emissions," Energy Systems and Policy, vol. 15, no. 211-235, 1992.

[45] P.N. Spotts, "Capping carbon," Christian Science Monitor, Dec. 14, 2000.

[46] R. Walker, "Keynote address-Understanding the challenge," presented at IEEE The Hydrogen Economy: Its Impact on the Future of Electricity Conf., Washington, DC, Apr. 19, 2004, www.ieee.org/power/hydrogen.

[47] D.W. Keith and A.E. Farrell, "Rethinking hydrogen cars," Science, vol. 301, July 18, 2003. [48] M. Hiltzik, "Hydrogen highway plans riding on misconceptions," Los Angeles Times, May 6, 2004.

[49] J.J. Romm, "The hype about hydrogen," Issues in Science and Technology, Spr. 2004.

[50] Office of Energy Efficiency and Renewable Energy, Hydrogen, Fuel Cells, and Infrastructure Technology Program, "National Hydrogen Energy Roadmap," U.S. Department of Energy, Washington, DC, November 2002, available online at http://www.eere.energy.gov /hydrogenandfuelcells/ pubs.html

[51] R.B. Shainker, "EPRI technology roadmap for the hydrogen-electric economy," presented at IEEE The Hydrogen Economy: Its Impact on the Future of Electricity Conf., Washington, DC, Apr. 20, 2004, www.ieee.org/power/hydrogen.

[52] American Physical Society, Panel on Public Affairs, The Hydrogen Initiative, Discussion Paper, Washington, DC, Mar. 2004, downloaded May 21, 2004 from http://www.aps.org/public_ affairs/index.cfm.

[53] C. Kaysen, S.E. Miller, M.B. Malin, W.D. Nordhaus, and J.D. Steinbruner, War with Iraq: Costs, Consequences, and Alternatives. Cambridge, MA: American Academy of Arts and Sciences, 2002.

[54] N. Matsakis and E. Vlanton, Cost of War, June 2004, http://costofwar.com/.

[55] U.S. Department of Energy, Energy Information Administration, Annual Energy Review 2002, Washington, DC, 2003.

[56] New Jersey Department of Environmental Protection, Final Report of the New Jersey Comparative Risk Project, Trenton, NJ, 2003, http://www.state.nj.us/dep/dsr/njcrp/index.htm [57] J. Rifkin, "The hydrogen economy: The creation of the worldwide energy web and the redistribution of power on earth," presented at IEEE The Hydrogen Economy: Its Impact on the Future of Electricity Conference, Washington, DC, Apr. 20, 2004, www.ieee.org/power/ fhydrogen.

[58] M.A. Weiss, J.B. Heywood, E.M. Drake, A. Schaefer, and F.F. Au Yeung, "On the road in 2020: A life cycle analysis of new automobile technologies," Energy Laboratory Rep. \#MIT EL 00-003, Massachusetts Institute of Technology, Cambridge, MA, Oct. 2000.

[59] M.A. Weiss, J.B. Heywood, A. Schaefer, and V.K. Natarajan, "Comparative assessment of fuel cell cars," Laboratory for Energy and the Environment Report \#MIT LFEE 2003001 RP, Massachusetts Institute of Technology, Cambridge, MA, Feb. 2003.

[60] U. Bossel, "Efficiency of hydrogen fuel cell, diesel-SOFC-hybrid and battery electric vehicles," working pap. available from European Fuel Cell Forum, Morgenstrasse 2F, CH5452 Oberrohrdorf, Switzerland, 2004b. 